\title{
The Non-finding of the Cultivation Effect in Iceland
}

\author{
GudBJöRg Hildur Kolbeins
}

It's been a quarter of a century since George Gerbner and his associates published a series of articles in the Journal of Communication on the cultivation hypothesis. They argued that television supplied its viewer with a distorted picture of reality. At the essence of the cultivation hypothesis is the fact that violence is rampant on television and it has been found that heavy viewers of television tend to believe that the world they live in is like the world they see on television. For example, heavy viewers of television overestimate the amount of those who are employed in law enforcement and they tend to report a higher sense of personal risk and mistrust (see for example Gerbner \& Gross, 1976; Gerbner et al., 1977; Gerbner et al., 1978; Gerbner et al., 1979 and Gerbner et al., 1980).

It should be noted that Gerbner has always maintained that the theory of cultivation is a theory of cumulative long-term exposure to television, NOT to exposure of specific genres (Gerbner, 1990).

The cultivation hypothesis has been heavily criticized over the years. For example, Doob and Macdonald (1979) found that heavy viewers of television are more likely to be afraid of their environment. However, and importantly, when one controls for the crime rate in people's neighborhoods, this relationship disappears. Gerbner and his colleagues reacted to this study by introducing the concept of "resonance", i.e. they argued that television violence amplifies the fear of those who are most likely to be victimized and those who live in high crime areas. A recent study by Shrum and Bischak (2001) found that the estimates of crime risk were significantly higher for those who had direct experience with crime and were heavy viewers of television than for those who also had direct experience with crime but were lighter viewers of television.

Despite Gerbner's claim that the cultivation effect is the consequence of people's total exposure to television, most studies in the area of cultivation research have looked at people's viewing of specific genres like crime drama and news. Recently, one study has looked at how crime coverage on network TV news has affected the viewers' perception of crime (Lowry et al., 2003).

It has been difficult to replicate the findings of U.S. cultivation studies abroad or among foreign audience in the U.S. In Australia, Hawkins and Pingree (1981) found that the so-called "Mean World"-index was associated with the sample's viewing of U.S. programs but not with viewing of non-U.S. programs. In Great Britain, Wober failed at first to find any cultivation effect among the British audience and concluded that "what may be true in America is not true in Britain" (Wober, 1978: 320). He did later find a 
significant relationship between viewing of U.S. crime drama and fear but NOT between viewing of British crime drama and fear (Wober, 1990).

It is the purpose of the present study to attempt to investigate whether one finds the cultivation effect in Iceland. The question is: Does viewing of television violence make Icelandic viewers distrust other people and more afraid of walking alone at night? Moreover, it will be studied whether the viewers' own delinquent behavior, and thus their own experience as offenders, affects the relationship between viewing of violence and the "Mean World"-syndrome. It may be expected that television violence amplifies the fear of those who have direct experience with crime.

\section{Methodology}

\section{Sample and Procedure}

The present study was conducted in Iceland in September and October, 2002. Questionnaires were administered by teachers to students in 8th through 10th grade in 15 schools in the Reykjavík-metropolitan area. Nine of the schools were located in Reykjavík, two in Kópavogur, two in Hafnarfjörður, one in Seltjarnarnes and one in Garðabær. Each school represented approximately 10.000 inhabitants. The students had 40 minutes, or one class hour, to complete the questionnaire. No problems were reported. The final sample included 965 participants.

\section{Independent and Dependent Variables}

The "Mean World"-syndrome was measured by asking the students to indicate on a four point scale whether they strongly disagreed, disagreed, agreed or strongly agreed with five statements. The statements were based on previous cultivation research (Signorielli, 1990). However, on purpose, all of the items were positively worded. The "Mean World"-index included the following statements: People are usually very helpful, Most people are honest, Most people can be trusted, It is safe to walk alone in downtown Reykjavík on a Saturday night, and It is safe to walk alone in my neighborhood on a Saturday night.

The "Mean World"-questions are usually pooled to make a scale but the reliability alpha was so low in this case that each question was used independently as a dependent variable. Age and gender were used as control variables in all of the analyses. Also, as the family plays an important role in the lives of adolescents and affects television viewing, the family cohesion and the family violence scales were used as controls (for further discussion on these scales, please see Kolbeins, 2002).

To measure the sample's viewing of television violence, the respondents were asked to indicate on a nine-point scale how often they watched crime drama, action programs and horror movies. Those three items were combined in a scale with a reliability alpha of .65

Delinquency was measured by 26 items which asked the respondents on a seven-point Likert-scale how often they had engaged in activities like stealing something from convenience stores, buying alcohol, damaging bus shelters etc. (see Kolbeins, 2002). Factor analysis of the items revealed five factors, i.e. vandalism, alcohol consumption, theft, serious offenses and drug abuse. This classification was consistent with findings from a previous study (Kolbeins, 2002). The items for each factor were combined into a scale and each scale recoded. A total score on a scale of 1 was recoded into 0 , which meant that the student had never engaged in any of the measured activities and a total score of 1,1 or higher was recoded as 1 - which meant that the student had engaged in at least one 
of the activities of that scale. The five scales were then combined to make a total delinquency score - with the highest possible number being 5 .

\section{Results}

Believing in People's Trustworthiness

The zero-order correlation between viewing of violence and each of the three statements (believing people are helpful, believing people are honest and believing it's possible to trust people) was non-significant. Simply put, there is absolutely no relationship between Icelandic adolescents' viewing of television violence and their trusting people.

Regression analysis revealed that age, gender and family cohesion/family violence all predicted the participants' trust in other people. As family cohesion/family violence are powerful predictors of delinquency, once they were removed as controls, delinquency also predicted the adolescents' trust or mistrust.

Younger children and girls are more trusting, and children from close-knit families are also more trusting. Not surprisingly, the more delinquent juveniles are less trusting. Viewing of television violence did not in any way predict the adolescents' belief in people's trustworthiness. By the same token, there was no indication that viewing of television violence resonated fear among those who were more delinquent.

\section{Feeling Safe Walking Alone at Night}

The zero-order correlations between feeling safe walking alone in one's own neighborhood and feeling safe walking alone in downtown Reykjavík were both significant. However, these relationships were not in the expected direction or like the cultivation hypothesis would predict. The zero-order correlation between viewing of violence and feeling it's safe to walk alone in one's own neighborhood was .12 and the zero-order correlation between viewing of violence and feeling it's safe to walk alone in downtown Reykjavík on a Saturday night was .08. Note that both of these correlations are positive! That is, the more the adolescents seemed to watch violence, the safer they felt walking alone at night.

All of the control variables, i.e. age, gender, family cohesion/family violence and delinquency predicted the adolescents' feeling that it was safe to walk alone in their own neighborhood. Older adolescents felt safer than the younger ones, boys felt safer than girls, and more delinquent adolescents felt safer than the less delinquent ones. Adolescents from cohesive families felt less safe. In addition, even after adding the control variables, the positive relationship between viewing of violence and feeling safe walking in one's own neighborhood at night was still significant.

The same results were found for the relationship between age, gender, family cohesion/family violence and delinquency and feeling safe walking alone in downtown Reykjavík. However, the relationship between television violence viewing and feeling safe, or unsafe, in downtown Reykjavík disappeared when the control variables were added to the regression.

\section{How about News?}

Studies, conducted in the U.S., have repeatedly shown that television news cultivates fear. Thus, it was felt necessary to look at if television news might cultivate fear even though violent television programs did not seem to do so. 
The adolescents' frequency of viewing of news, news programs, discussion programs and documentaries was scaled into one variable with a reliability alpha of .71 .

There was no relationship between viewing of news programs and believing it's safe to walk alone in one's own neighborhood. However, the correlation between viewing of news programs and feeling safe walking around downtown Reykjavík was significant and in the predicted direction (-.08). It seemed that the more the adolescents watched news programs, the more afraid they were walking alone at night in downtown Reykjavík - just as the cultivation hypothesis would predict.

As family cohesion/family violence predict viewing of news, those variables were added as controls, and as expected, the relationship between viewing of news and feeling unsafe in downtown Reykjavík became non-significant.

\section{Discussion}

The present study tried to examine whether Gerbner's arguments about television gradually cultivating fear and mistrust in its viewers held true among Icelandic teenage viewers. The results indicate that there is absolutely no evidence for the cultivation effect in Iceland. On the contrary, it was found that the more the adolescents watched violence on television, the safer they felt walking alone at night in their own neighborhood. Interestingly, these results are consistent with the findings of Tamborini and Choi (1990). They found that the more Korean university students in the U.S. watched crime-related entertainment, the safer they felt walking alone in their own neighborhoods. Unfortunately, Tamborini and Choi did not offer any explanation for their findings.

It has to be admitted that one cannot easily come up with an explanation for these unexpected and surprising results. Two related explanations may be possible. Firstly, watching television violence teaches adolescents how to apply force or defend themselves if someone attacks them. Thus, the adolescents may feel that if they are attacked when walking alone, they know how to defend themselves. Secondly, it is known that viewing violence makes one immune to interpersonal violence. Thus, those who are heavy viewers of violence may be immunized to the discussion on violence and the crime rate in Reykjavík or their own town. Or the adolescents may simply believe that compared to the U.S., for example, it is quite safe to walk alone in Iceland. Also, it is quite possible that they are so fully aware that the crime programs take place in another country, mostly the U.S., that they don't even consider that what's happening on television may happen in Iceland. It should be kept in mind, of course, that the crime rate in Iceland is miniscule compared to the crime rate in the U.S.

The studies by Hawkins and Pingree (1981) and Wober (1990) have previously found some evidence for the cultivation effect in Australia and Great Britain but their results were contingent on the audience viewing of U.S. programming. They did not find any relationship between their samples viewing of non-U.S. programs and the "Mean World"syndrome.

Although studies which have been conducted in the U.S. have repeatedly found a relationship between people's viewing of television and their feeling of insecurity and fear, non-U.S. research has for the most part failed to replicate those findings. Once again, a cultivation study, carried out outside of the U.S. has failed to find support for the cultivation hypothesis.

Keeping in mind the findings of the present study and the findings of other non-U.S. studies on the cultivation effect, one can easily make the claim, based on the known 
evidence, that the cultivation hypothesis is only/mostly applicable to the U.S. audience in the United States. Borrowing from Wober, one can argue that what may be true in America is not true in the rest of the world. Which brings one to the question, why have cultivation studies outside of the U.S. consistently failed to replicate the findings of the U.S. studies?

The first and most obvious reason is probably the different nature of television programming in the U.S. compared to other countries. At the heart of Gerbner's hypothesis lies the assumption that all television programs carry the same underlying message to the audience. Gerbner and his colleagues have pointed out in the past that American television portrays a distorted picture of reality where crime, for example, is much more common than in the real world. Consequently, the members of the television audience are told time and again that they live in a dangerous world and shouldn't trust anyone - which then makes them distrustful and paranoid. In a nutshell, the world of American television is a world of crimes and criminals. This is supported by the fact that people's viewing of American programs but not their viewing of non-U.S. programs has been found to be related to their perception of fear.

Although U.S. television programs, among them popular U.S. crime drama, wheigh heavily in the viewing diet of the Icelandic audience, viewers are, at least to some degree, also exposed to programming from their own country and other European countries, mostly Great Britain. It's certainly true that British programming portrays crimes and criminals but as Wober found, British crime drama does not, for some reason, cultivate fear in its viewers. This may be due to certain differences between British and American crime drama.

Thus, even though Icelandic adolescents are heavy viewers of U.S. crime drama and U.S. action shows, their viewing doesn't cultivate in them any fear of their own environment or make them distrustful of other people because they are not exclusively exposed to the American television version of reality as their U.S. counterparts. It may be said that the Icelandic viewers are getting a more balanced view of reality and that any influence that U.S. programming may have on their perceptions of reality is counterbalanced by programming from their own country and other countries. It is thus argued that the lack of the cultivation effect in other countries is simply due to the fact that Gerbner's assumption about the world of television and its messages is only applicable to and true for U.S. television and that the overall message of non-U.S. programs does not emphasize crime or a sense of insecurity.

The present study did not look at the effects of viewing of television violence on the adolescents' perception of the U.S. It is quite possible that viewing of television violence, especially viewing of U.S. crime drama like Law \& Order, is cultivating fear of the U.S. in Icelandic adolescents even though U.S. crime drama is not cultivating fear in them of their own environment.

Moreover, the nature of the American society per se may be a contributing factor to the existance of the cultivation effect in the U.S. As the social critic Michael Moore so poignantly pointed out in his award-winning documentary Bowling for Columbine, there is a certain obsession with crime and violence among Americans - an obsession which television distorts and amplifies. The crime rate and the ownership of guns is generally lower in European countries, for example, than in the United States. Europeans should therefore have a stronger sense of security and feel safer in their own environment than Americans, making them less likely to be influenced by television. 
To summarize, as the present study failed to find support for the cultivation hypothesis, it is proposed that the cultivation effect of television is to be found where the audience is exposed to only one television reality, a reality portrayed by people and for people whose own culture puts vast emphasis on violence and encourages the feeling of fear.

\section{Bibliography}

Doob, A.N. \& Macdonald, G.E. (1979) Television Viewing and Fear of Victimization: Is the Relationship Causal? Journal of Personality and Social Psychology, 37(2), pp. 170-179.

Gerbner, G. (1990) Epilogue: Advancing on the Path of Righteousness (maybe). In Signorielli, N. \& Morgan, M. (Eds.). Cultivation Analysis: New Directions in Media Effects Research. Newbury Park, California: Sage Publications.

Gerbner, G. \& Gross, L. Living with Television: The Violence Profile. Journal of Communication, 1976, 26(2), 173-199.

Gerbner, G., Gross, L., Eleey, M.F., Jackson-Beeck, M., Jeffries-Fox, S. \& Signorielli, N. (1977) TV Violence Profile no. 8: The Highlights. Journal of Communication, 27(2), pp. 171-180.

Gerbner, G., Gross, L., Jackson-Beeck, M., Jeffries-Fox, S. \& Signorielli, N. (1978) Cultural Indicators: Violence Profile no. 9. Journal of Communication, 1978, 28(3), pp. 176-207.

Gerbner, G., Gross, L., Morgan, M. \& Signorielli, N. (1980) The "Mainstreaming" of America: Violence Profile no. 11. Journal of Communication, 30(3), pp. 10-29.

Gerbner, G., Gross, L., Signorielli, N., Morgan, M. \& Jackson-Beeck, M. (1979) The Demonstration of Power: Violence Profile no. 10. Journal of Communication, 29(3), pp. 177-196.

Kolbeins, G.H. (2002) Delinquency and Adolescents' Viewing of Tlevision Volence. Nordicom Review (Special issue), 23(1-2), pp. 277-290.

Lowry, D.T., Nio, T.C.J. \& Leitner, D.W. (2003) Setting the Public Fear Agenda: A Longitudinal Analysis of Network TV Crime Reporting, Public Perceptions of Crime and FBI Crime Statistics. Journal of Communication, pp. 61-73.

Pingree, S. \& Hawkins, R. (1981) U.S. Programs on Australian Television: The Cultivation Effect, Journal of Communication, pp. 31(1), 97-105.

Shrum, L.J. \& Bischak, V.D. (2001) Mainstreaming, Resonance, and Impersonal Impact: Testing Moderators of the Cultivation Effect for Estimates of Crime Risk. Human Communication Research, 27(2), pp. 187-215.

Signorielli, N. (1990) Television's Mean and Dangerous World: A Continuation of the Cultural Indicators Perspective. In Signorielli, N. \& Morgan, M. (Eds.) Cultivation Analysis: New Directions in Media Effects Research. Newbury Park, California: Sage Publications.

Tamborini, R. \& Choi, J. (1990) The Role of Cultural Diversity in Cultivation Research. In Signorielli, N. \& Morgan, M. (Eds.) Cultivation Analysis: New Directions in Media Effects Research. Newbury Park, California: Sage Publications.

Wober, J.M. (1978) Televised Violence and Paranoid Perception: The View from Great Britain. Public Opinion Quarterly, 42, pp. 315-321.

Wober, J.M. (1990) Does Television Cultivate the British: Late '80s Evidence. In Signorielli, N. \& Morgan, M. (Eds.) Cultivation Analysis: New Directions in Media Effects Research. Newbury Park, California: Sage Publications. 